\title{
Perubahan Tingkah Laku Tokoh Saya dalam Novel "Jangan Sisakan Nasi dalam Piring" Karya Kembangmanggis: Perspektif Behaviorisme Skinner
}

\author{
Mufadila Fibiani $^{1}$, Ekarini Saraswati ${ }^{2}$ \\ Pendidikan Bahasa dan Sastra Indonesia Fakultas Keguruan dan Ilmu Pendidikan \\ Universitas Muhammadiyah Malang \\ fmufadila@.com ${ }^{1}$, ekarini@umm.ac.id ${ }^{2}$
}

DOI: https://doi.org/10.32528/bb.v5i2.3273

First received: 31-05-2020

Final proof received: 24-09-2020

\begin{abstract}
ABSTRAK
Tingkah laku merupakan rangkaian sebab akibat dari adanya stimulus dan respon. Respon terjadi akibat dari adanya stimulus yang diberikan. Berkaitan dengan hal tersebut, penelitian ini bertujuan untuk membedah perubahan tingkah laku tokoh saya melalui stimulus respon yang terjadi dalam novel Jangan Sisakan Nasi dalam Piring karya Kembangmanggis selama tinggal di Ubud, Bali. Penelitian ini merupakan penelitian deskriptif kualitatif dengan pendekatan psikologi sastra. Teknik pengumpulan data yang yang digunakan dalam penelitian ini yaitu studi pustaka. Teknik analisis data dalam penelitian ini adalah deskriptif kualitatif yang diawali dengan analisis data, deskripsi hasil klasifikasi, dan kesimpulan. Hasil penelitian menunjukkan bahwa selama tokoh saya tinggal di Ubud, Bali banyak pelajaran hidup yang didapatkannya. Pembelajaran tersebut didapatkan melalui stimulus dan respon yang diterima dan ditunjukkan oleh tokoh saya melalui perspektif behaviorisme Skinner. Adapun perubahan tingkah laku tokoh saya yang ditunjukkan berupa lebih menghargai pemberian, lebih menghargai pekerjaan, dan lebih menghargai orang lain. Menghargai pemberian ditunjukkan dengan adanya stimulus yang diberikan oleh Pak Jumu, Bapak Nangka, dan lingkungan Ubud. Menghargai pekerjaan ditunjukkan dengan adanya stimulus yang diberikan oleh lingkungan, dalam hal ini peristiwa panen. Terakhir, menghargai orang lain ditunjukkan dengan adanya stimulus yang diberikan oleh tokoh $\mathrm{Bu}$ Klengis
\end{abstract}

Kata kunci: tingkah laku; behaviorisme; skinner; novel

\begin{abstract}
Behavior is a series of causes and effects from the stimulus and response. The response occurs as a result of the stimulus provided. In this regard, this study aims to dissect changes in my character's behavior through the stimulus response that occurs in the novel Do not Leave Nasi in a Plate by Kembangmanggis while living in Ubud, Bali. This research is a qualitative descriptive study with a psychology literature approach. The data technique used in this research is literature study. The data analysis
\end{abstract}


technique in this research is descriptive qualitative beginning with data analysis, a description of the classification results, and conclusions. The results showed that during the time my character lived in Ubud, Bali he learned many life lessons. The learning was obtained through the stimulus and response my character received and demonstrated through the perspective of Skinner's behaviorism. As for the character change in my behavior, it was shown to be more respectful, more appreciative of work, and more respectful of others. Appreciation was given shown by the stimulus provided by Mr. Jumu, Mr. Nangka, and the Ubud environment. Appreciating work is shown by the stimulus provided by the environment, in this event the harvest event. Lastly, respect for others as shown by the stimulus provided by the character $\mathrm{Bu}$ Klengis Keywords: behavior; behaviorism; skinner; novels

\section{PENDAHULUAN}

Karya sastra merupakan hasil imajinasi pengarang mengenai suatu kehidupan. Artinya, pengarang bebas memaknai kehidupan melalui tokoh serta peristiwa yang dibangun dalam karya sastra tersebut. Meskipun pemaknaan antara pengarang yang satu dengan pengarang yang lain berbeda terhadap suatu peristiwa, akan tetapi kehidupan adalah satu tema besar yang melatarbelakangi ide-ide pengarang tersebut sehingga pada dasarnya semua pengarang meletakkan satu tema tertinggi yaitu pada kehidupan (Astari, Qomariyah, \& Andalas, 2019, p. 70). Peristiwa-peristiwa dalam kehidupan diangkat menjadi sebuah tema oleh pengarang menggunakan media. Media tersebut dapat berupa puisi, novel, cerpen, dan karya sastra yang lainnya. Adapun karya sastra yang penulis gunakan dalam penelitian ini yaitu novel Jangan Sisakan Nasi dalam Piring karya Kembangmanggis.

Novel Jangan Sisakan Nasi dalam Piring karya Kembangmanggis diterbitkan oleh Gramedia Pustaka Utama pada Desember 2018. Novel dengan jumlah 224 halaman ini ditulis oleh Kembangmanggis, penulis novel dan cerpen yang terkenal pada tahun 1980-an. Baby Ahnan, yang merupakan nama asli dari Kembangmanggis merupakan pebisnis kuliner sejak 1999, sehingga tidak mengherankan jika di beberapa ceritanya menyuguhkan tema kuliner. Novel dengan 220 halaman ini memenangkan penghargaan Adikarya dari Ikatan Penerbit Indonesia tahun 2003.

Melalui 23 kisah ringan mengenai Ubud-Bali yang terdapat di novel ini, Kembangmanggis berhasil membius pembaca dengan pilihan kata yang mudah dipahami. Sampul buku dengan pilihan warna hitam dan putih ditambah sketsa objek membuat estetika novel ini semakin hidup. Selain itu, setiap bagian juga disisipi sketsa gambar yang menjelaskan bagian tersebut. Jarak antar paragraf dibuat lumayan panjang sehingga pembaca tidak merasa bosan saat membacanya. Ukuran hurufnya juga tidak teralu kecil, sehingga pembaca terkesan menikmati saat mebacanya. Hanya saja, novel ini tidak disertai pembatas seperti novel-novel lain sehingga pembaca harus mencari pembatas sendiri ketika membaca novel ini dan berniat menyelesaikannya di lain waktu. Novel ini menceritakan tokoh saya yang sedang bermukim di Ubud-Bali bersama dengan kedua anaknya, Anggit dan Nala. Mereka berasal dari Bogor. Tokoh saya yang merupakan pebisnis kuliner di Bogor nampak terpesona dengan keindahan serta 
kehidupan sosial di Ubud hingga pada akhirnya ia mendirikan studio kecil di Bisma sebagai tempat tinggal tokoh saya dan kedua anaknya. Sebelum mendirikan studio kecil ini mereka selalu bermalam di Brata Homestay, penginapan langganan ketika berkunjung ke Bali. Studio kecil tersebut berdiri atas bantuan Pak Edi yang baik hati. Baik hati, lantaran ia selalu memberikan koleksi kayunya bagi siapapun yang membutuhkan. Selain itu Pak Edi juga hanya mengambil keuntungan kecil pada proyek pembangunan studio itu. Ia mengaku tertarik dengan sketsa studio itu sehingga saat tokoh saya menyodorkan sketsa untuk studio yang kedua, Pak Edi nampak bersemangat sekali.

Masyarakat di Ubud adalah masyarakat yang masih memegang erat tradisi. Beberapa tradisi telah ditemukan oleh tokoh saya dan kedua anaknya salah satunya keinginan memberi terhadap sesama yang cukup tinggi. Sawah-sawah yang membentang luas, menguning dan menghijau pada masanya serta panorama-panorama alami lain yang masih bersifat tradisional membuat mereka menjadikan Ubud, Bali sebagai tempat berkunjung saat liburan tiba.

Tokoh-tokoh dalam novel ini cukup banyak namun cara eksplisit hanya sedikit yang menunjukkan sifat antagonis. Cerita dalam novel ini bukan cerita yang menyuguhkan konflik yang berat, akan tetapi Kembangmanggis menyuguhkan cerita yang dapat dinikmati dengan secangkir kopi untuk mengisi waktu santai. Tokoh saya dengan kedua anaknya juga merupakan pecinta hewan. Hal ini tergambar dalam cerita bahwa mereka telah menyembuhkan bebek, anjing, dan monyet. Perubahan tingkah laku tokoh saya terhadap lingkungannya merupakan hasil stimulus dari lingkungan. Selain itu, adanya stimulus dan respon dari tokoh lain juga yang kemudian menjadi alasan peneliti untuk meneliti tokoh saya dalam novel Jangan Sisakan Nasi dalam Piring karya Kembangmanggis.

Berdasarkan isi novel tersebut, penelitian ini mengarah pada perubahan tingkah laku dari tokoh saya melalui stimulus respon menurut perspektif skinner. Tujuan penelitian ini adalah untuk membedah bentuk-bentuk perubahan tingkah laku pada tokoh saya dalam novel Jangan Sisakan Nasi dalam Piring karya Kembangmanggis. Penelitian mengenai perubahan tingkah laku penting dilakukan karena beberapa alasan, diantaranya, 1) mengubah persepsi sebagian masyarakat bahwa tingkah laku tercipta karena adanya stimulus, bukan semata-mata dilakukan tanpa alasan; 2) tingkah laku dapat berubah sesuai lingkungan serta stimulus yang diberikan, sehingga tidak menutup kemungkinan bahwa tingkah laku seseorang dapat berubah sewaktu-waktu.

Adapun manfaat dalam penelitian ini yaitu; 1) sebagai bentuk pemahaman secara kritis bahwa tingkah laku seseorang dapat berubah sesuai stimulus yang diberikan; 2) sebagai bentuk pemahaman kritis bahwa setelah stimulus diberikan ada dua kemungkinan yaitu merespon sesuai tujuan atau yang bertolak belakang dengan tujuan stimulus yang diberikan 3) menambah literatur mengenai tingkah laku berdasarkan perspektif Skinner bagi para pembaca.

Penelitian mengenai perubahan tingkah laku telah dilakukan oleh Partiningsih (2018) dengan judul Kepribadian Behaviorisme Tokoh Anya dalam Novel Critical Eleven Karya Ika Natassa: Kajian Psikologi Skinner. Hasil penelitian ini menunjukkan 
bahwa tokoh Anya mengalami sebuah pola belajar behaviorisme, ia belajar dari lingkungan baru yang ia temui, terjadi sebuah stimulus yang diberikan sehingga tokoh Anya ini merespon dari adanya sebuah stimulus yang diberikan tokoh Ale. Respon yang didapatkan Anya bergantung stimulus yang diberikan tokoh Ale. Awalnya tokoh Anya ini sangat mempercayai tokoh Ale sampai Anya benar-benar tidak menghiraukan tokoh Ale, tetapi rangsangan tersebut selalu diberikan oleh tokoh Ale sehingga pada akhirnya tokoh Anya ini memiliki kepribadian tingkah laku yang kembali peduli kepadanya seperti awal pertemuan mereka di pesawat saat itu.

Penelitian mengenai perubahan tingkah laku juga telah dilakukan oleh Dewi Alifasari (2017) dengan judul Kepribadian Tokoh Jiwa dalam Novel Lelaki Terakhir yang Menangis di Bumi Karya M Aan Mansyur (Kajian Psikologi Behaviorisme B.F. Skinner). Hasil penelitian menunjukkan bahwa tokoh Jiwa(tokoh utama) mengalami suatu proses belajar yang sangat dipengaruhi oleh lingkungan (keluarga, sekolah, maupun masyarakat). Berbagai stimulus yang diterima menjadikannya mengalami perubahan perilaku yang dapat diamati secara nyata dalam sudut pandang behaviorisme B.F. Skinner. Akibat dari stimulus yang diberikan oleh berbagai lingkungan tersebut menghasilkan sebuah respon pada perilaku Jiwa baik respon positif maupun negatif.

Adapun perbedaan yang terdapat dalam penelitian ini dengan penelitian sebelumnya, bahwa dalam penelitian ini perubahan tingkah laku yang tergambar dalam novel Jangan Sisakan Nasi dalam Piring karya Kembangmanggis mengarah pada perubahan yang bersifat pemahaman atau sering disebut pola pikir yang menjadikan tokoh saya akan melakukan perubahan tingkah lakunya dikemudian hari. Sedangkan pada kedua penelitian tekait di atas, keduanya berfokus pada tingkah laku yang bersifat fisik, artinya tingkah laku yang langsung berubah dalam tempo yang cepat. Untuk memecahkan rumusan masalah tersebut, penulis enggunakan pendekatan psikologi sastra dengan teori behaviorisme B.F Skinner. Menurut (Ramadhan, 2019, p. 8) pada dasarnya, psikologi dan sastra memiliki kesamaan yaitu membahas manusia sebagai makhluk individu dan sosial. Perbedaan keduanya terletak pada objek pembahasan. Psikologi membicarakan manusia sebagai sosok yang murni ciptaan Tuhan, sedangkan pada karya sastra objek yang dibahas adalah tokoh-tokoh yang diciptakan oleh seorang pengarang atau bisa juga disebut tokoh imajinasi.

Perubahan tingkah laku terjadi karena adanya stimulus respon. Hal ini sejalan dengan pendapat (Endraswara dalam Romadhon, 2015, p. 20) bahwa perilaku manusia selalu berhubungan karena dimulai dari adanya pemberian stimulus yang kemudian terciptanya respon. Dengan demikian, konsep dari Endraswara inilah yang kemudian meninggalkan unsur insting, perasaan, serta pembawaan individu sejak lahir (Romadhon, 2015, p. 20). Dengan demikian, inilah pandangan behaviorisme yang mengacu pada lingkungan sebagai pembentuk tingkah laku suatu individu.

\section{METODE}

Jenis penelitian ini adalah deskriptif kualitatif. Penelitian deskriptif kualitatif adalah penelitian yang datanya berupa unit-unit teks dan deskripsi kalimat-kalimat yang sesuai dengan objek penelitian (Kharisma, 2018, p. 1). Pendekatan yang digunakan 
dalam penelitian ini adalah pendekatan psikologi sastra. Psikologi sastra memiliki arti bahwa kajian sastra yang memandang karya sastra sebagai aktivitas kejiwaan sehingga pengarang menggunakan cipta dan rasa dalam berkarya (Partiningsih, 2018, p. 7).

Sumber data penelitian ini berupa novel Jangan Sisakan Nasi dalam Piring karya Kembangmanggis. Data penelitian ini berupa narasi, perilaku tokoh, dan dialog yang menunjukkan adanya perubahan tingkah laku tokoh saya dalam novel.

Instrumen penelitian ini berupa peneliti itu sendiri. Peneliti bertindak menjadi segalanya dalam proses penelitian mulai dari perencana, pelaksana, pengumpul data, penganalisis, dan penarikan kesimpulan sehingga peneliti dikatakan sebagai instrumen (Andalas, 2017, p. 188).

Teknik pengumpul data yang digunakan dalam penelitian ini yaitu studi pustaka. Teknik studi pustaka merupakan teknik yang menggunakan sumber-sumber tertulis untuk memperoleh data sesuai dengan rumusan masalah (Partiningsih, 2018, p. 8). Adapun sumber tertulis yang terdapat dalam penelitian ini yaitu novel itu sendiri.

Teknik analisis data yang digunakan dalam penelitian ini yaitu deskriptif analitik. Teknik deskriptif analitik dilakukan dengan cara mendeskripsikan fakta-fakta yang ada dalam sumber data, yang kemudian dilanjut dengan analisis (Ratna, 2013, p. 53). Adapun langkah-langkahnya sebagai berikut. 1) menganalisis data dari klasifikasi data yang telah dilakukan pada saat pengumpulan data. 2) mendeskripsikan hasil klasifikasi data dalam bentuk uraian yang bersifat naratif. Bentuk perubahan tokoh saya yang terdapat dalam novel dideskripsikan dan dianalisis untuk menjawab rumusan masalah.

3) menyimpulkan data dari hasil analisis dengan memberikan garis besar dari pokok permasalahan dengan perspektif stimulus respon dari skinner.

\section{HASIL DAN PEMBAHASAN}

Novel Jangan Sisakan Nasi dalam Piring menceritakan suasana kehidupan tokoh saya dan kedua anaknya di Ubud, Bali. Mereka cukup akrab dengan orang-orang setempat serta banyak pelajaran hidup yang didapatkan oleh tokoh saya selama berada di sana. Melalui narasi, dialog, dan perilaku tokoh, penulis menemukan perubahan tingkah laku dari tokoh saya melalui stimulus dan respon yang terjadi. Adapun perubahan tingkah laku tersebut yaitu berupa tingkah laku sikap yaitu menghargai pemberian, menghargai pekerjaan, dan menghargai orang lain yang akan diuraikan sebagai berikut

\section{a. Menghargai Pemberian}

Sebagai makhluk sosial saling memberi adalah sikap yang harus ditanamkan pada masing-masing individu. Penanaman sikap tersebut telah banyak disisipkan pada sekolah-sekolah saat ini yang akrab disebut sebagai penanaman karakter. Menghargai pemberian merupakan respon dari adanya pemberian terhadap sesuatu. Hal inilah yang tergambar dalam masyarakat Ubud, Bali yang kental dalam hal berbagi. Pemberian merupakan salah satu contoh stimulus yang sering terjadi dalam lingkungan sekitar.

Stimulus merupakan sesuatu yang mempengaruhi individu dalam bertingkah laku yang datang dari luar individu tersebut, baik dari lingkungan sosial ataupun 
tingkah laku dari individu lain yang menimbulkan suatu perilaku pada individu tersebut (Alifasari, 2017, p. 4). Dalam novel Jangan Sisakan Nasi dalam Piring, tokoh saya mengalami stimulus seperti pada kutipan berikut

Saat belum kenal aturannya, saya mengejar Pak Purna untuk mengembalikan telur yang saya temukan. Waktu itu Pak Purna masih sombong. Dia hanya menggoyang-goyangkan tongkat panjang di tangannya dan ngeloyor menggiring bebek-bebeknya pergi. Acuh tak-acuh (Kembangmanggis, 2018, p. 21-22).

Kutipan di atas merupakan bentuk stimulus yang diberikan lingkungan kepada tokoh saya. Artinya, lingkungan telah membut tokoh saya melakukan suatu tingkah laku. Tokoh saya saat itu belum paham mengenai aturan telur yang berada di pematang sawah Ubud. Dalam narasi lain, diceritakan bahwa masyarakat Ubud begitu memiliki sifat memberi yang luar biasa tinggi. Salah satu bentuk pemberiannya adalah telur-telur bebek yang tergeletak di luar kandang dianggap sebagai rezeqi orang yang menemukan. Para petani bebek hanya berhak memiliki telur yang berada di kandang saja. Hal inilah yang saat itu tengah dialami oeh tokoh saya. Ia adalah orang asli Bogor yang saat itu baru tinggal di Ubud. Telur-telur bebek yang tergeletak di pematang adalah bentuk stimulus kepada tokoh saya.

Berdasarkan teori Behaviorisme Skinner, telur-telur yang ada di sawah inilah yang disebut bentuk stimulus. Stimulus tersebut datang dari lingkungan tanpa suatu komunikasi namun stimulus tetap tersampaikan kepada tokoh saya. Hal ini dibuktikan dengan perilaku tokoh saya yang kemudian mengejar Pak Purna untuk mengembalikan telur-telurnya. Menurut (Mauludiyah, Mudjianto, \& Kamal, 2012, p. 2) ada dua jenis stimulus, yaitu stimulus tak berkondisi dan stimulus yang berkondisi. Stimulus tak berkondisi berarti bahwa sifatnya alami, lingkungan sosial benar-benar masuk ke dalam jenis stimulus ini. Sedangkan stimulus berkondisi maksudnya stimulus yang terjadi akibat campur tangan manusia guna berperilaku sesuai dengan tujuannya. Berdasarkan stimulus yang diberikan, tokoh saya kemudian mengalami perubahan tingkah laku seperti pada kutipan berikut.

Jadi, bangun tidur pagi-pagi di studio, bagi saya setiap hari adalah hari Paskah! Saat fajar merekah, acara pertama pasti mencari-cari telur di pematang sawah (Kembangmanggis, 2018, p. 21)

Uraian di atas menggambarkan bahwa bentuk respon dari tokoh saya terhadap stimulus yang diberikan yaitu berupa rasa senang. Suryabrata (dalam Zaini, 2014, p. 122) membagi respon menjadi dua, yaitu reflexive response dan instrumental response. Reflexive response timbul karena adanya perangsang-perangsang tertentu yang sifatnya cenderung tetap. Contoh, air liur merupakan bentuk respon dari adanya makanan. Respon inilah yang dinamakan cenderung tetap. Selanjutnya, instrumental response, yaitu respon yang timbul dan berkembang karena adanya rangsangan-rangsangan 
tertentu. Perangsang-perangsang tersebut bersifat memperkuat respon sehingga kekuatan perangsang tersebut mempengaruhi kekuatan tingkah lakunya. Contoh: seseorang yang telah melakukan belajar dan mendapat hadiah akan semakin giat belajarnya. Adapun bentuk pemberian lain oleh masyarakat Bali yang tergambar dalam novel Jangan Sisakan Nasi dalam Piring adalah sebagai berikut.

Si bapak melotot. "tidak usah bayar!” katanya marah. "Bawa buat anak-anak!” (Kembangmanggis, 2018, p. 60).

Kegiatan masyarakat Bali terutama Ubud yang suka memberi juga tergambar dalam kutipan di atas. Bapak yang ada kutipan itu adalah Bapak Nangka, sebutan dari tokoh saya dan kedua anaknya. Tempat berjualannya di warung yang terletak di ujung jalan yang sepi. Ia berjualan pisang goreng saat itu. Tokoh saya dan kedua anaknya tengah tersasar di hutan dan kemudian membeli di warung itu sekaligus menanyakan jalan pulang. Di akhir interaksi, bapak Nangka tersebut memaksa untuk tetap memberikan nangkanya.

Pada kutipan di atas, jenis stimulus yang diterima oleh tokoh saya adalah stimulus terkondisi. Stimulus ini diberikan dengan tujuan menghasilkan perilaku sesuai dengan yang diinginkan (Alifasari, 2017, p. 4). Stimulus tersebut diberikan oleh Bapak Nangka kepada tokoh saya. Bentuk respon yang ditunjukkan oleh tokoh saya adalah sebagai berikut.

Setelah peristiwa itu, setiap kali saya datang ke Ubud, sudah menjadi acara tetap kami untuk tersasar lagi ke pelosok mencari waeung kecil si bapak nangka. Sekadar membawakannya oleh-oleh dari Bogor. Apa saja. Saya, Anggit, dan Nala berutang padanya sebuah ketulusan pemberian. (Kembangmanggis, 2018, p. 64).

Kutipan di atas merupakan bentuk respon dari tokoh saya terhadap pemberian Bapak Nangka. Bentuk respon yang ditunjukkan berupa kesadaran atas ketulusan sebuah pemberian. Pada awalnya memang tokoh saya sempat jengkel dengan Bapak Nangka lantaran ia memaksa tokoh saya untuk menerima pemberiannya. Tokoh saya beranggapan bahwa nangka pucat itu pasti rasanya tidak enak sehingga ia tidak mau menerimanya. Namun, setelah tokoh saya dan kedua anaknya mencicipi nangka tersebut ternyata nangkanya sangat manis. Maka dari itulah tokoh saya dan kedua anaknya selalu setia mengunjungi warung Bapak Nangka ketika datang ke Ubud. Bentuk pemberian lain sebagai ciri khas masyarakat Ubud sebagai bentuk stimulus adalah sebagai berikut

"Ya. Roti. Ibu mau?" tanya Pak Jumu ragu-ragu

(Kembangmanggis, 2018, p. 68).

Pada kutipan di atas tergambar bahwa Pak Jumu tengah menawari roti kepada tokoh saya. Roti tersebut Pak Jumu dapatkan dari tempat sampah pemilik bisnis pastry. Ia memiliki prinsip bahwa penjualan hari ini mengandalkan pembuatan hari ini. Jika masih tersisa, maka akan dibuang. Setiap paginya, Pak Jumu mengambil sisa-sisa roti yang masih layak makan itu di tempat sampah dekat hotel. Bagi Pak Jumu, roti-roti ini 
sangat membantunya karena bebek-bebknya pun juga ikut makan, sehingga mengurangi jumlah konsentrat.

Sikap Pak Jumu yang menawari tokoh saya roti itu dalam teori behaviorisme Skinner termasuk dalam stimulus terkondisi. Hal ini dikarenakan Pak Jumu memiliki tujuan agar tokoh saya mau menerima roti pemberiannnya. Dengan demikian, adanya campur tangan manusia dalam proses pemberian stimulus tergolong ke dalam stimulus terkondisi. Adapun bentuk respon yan ditunjukkan oleh tokoh saya sebagai berikut.

Memang banyak sekali. Saya memilih sebuah. Danish kayu
manis dengan raisin bertaburan di atasnya. Hmm, tampak
enak sekali. Harum sekali. Bentuknya menggiurkan. Berulir
dan berkilau bagian atasnya (Kembangmanggis, 2018, p. 69).

Kutipan di atas terjadi saat pagi hari ketika tokoh saya mendapati Pak Jumu sedang berjalan sambil membawa plastik besar. Ternyata plastik tersebut berisi banyak roti yang Pak Jumu dapatkan dari tempat sampah di hotel baru yang letaknya dekat dari situ. Tokoh saya yang menegur Pak Jumu pun akhirnya mengetahui asal-usul roti tersebut. Setelah mendapatkan stimulus berupa pemberian dari Pak Jumu, akhirnya tokoh saya pun menerimanya. Ia memilih sebuah roti Danish. Menerima pemberian inilah yang termasuk dalam bentuk respon. Bentuk respon yang tergambar dari tokoh saya ini termasuk ke dalam jenis instrumental respon karena adanya rangsanganrangsangan tertentu yang kemudian menyebabkan penerima stimulus tersebut semakin memperkuat bentuk responnya.

\section{b. Menghargai Pekerjaan}

Tokoh saya merupakan pebisnis kuliner di kota asalnya, yaitu Bogor. Dalam kedatangannya di Ubud, ia mendapatkan kesempatan langsung untuk menonton peristiwa panen. Hal ini tergambar pada kutipan sebagai berikut.

Pagi itu, sekumpulan orang telah berkumpul di sawah. Entah
datang dari mana saja. Laki-laki; perempuan, tua; muda.
Warna-warni baju mereka tampak kontras dengan sawah
menguning yang melatarbelakanginya. Suara obrolan
mereka terdengar sampai ke sudio (Kembangmanggis, 2018,
p. 75-76).

Berdasarkan kutipan di atas, kondisi lingkungan studio tokoh saya tengah ramai oleh banyak orang. Pada narasi lain diceritakan bahwa awalnya tokoh saya mengira akan terjadi upacara adat. Tetapi yang kemudian ia ketahui, ternyata akan terjadi kegiatan panen di sawah itu. Berdasarkan uraian ini, tidak ada individu yang secara sengaja memberi stimulus pada tokoh saya. Hanya saja lingkungan yang ramai yang kemudian mebuat tokoh saya penasaran. Meskipun asal suara tersebut berawal dari para petani yang hendak memanen sawah, akan tetapi para petani tersebut tidak memiliki tujuan sama sekali terhadap pemberian stimulus kepada tokoh saya sehingga menurut teori Behaviorisme Skinner, stimulus seperti ini tetap masuk ke dalam jenis stimulus tak terkondisi. Artinya, secara tidak langsung lingkungan telah membuat tokoh saya bertingkah laku dalam hal ini penasaran. 
Ubud, selain terkenal dengan pemberiannya juga terkenal dengan panorama lingkungan yang masih tradisional. Bentangan sawah masih menghijau dan menguning di mana-mana. Adapun respon terkait dengan keadaan ini dari tokoh saya adalah seperti pada kutipan berikut.

Saya buru-buru men-charge baterai kamera. Pasti asyik sekali membidiki foto-fotonya (Kembangmanggis, 2018, p. 77).

Situasi yang terjadi pada gambaran kutipan di atas adalah saat panen tiba. Tokoh saya yang berasal dari kota tampak semangat ketika diberi tahu Pak Jumu bahwa orangorang yang berkumpul di sawah itu hendak memanen padi. Bagi tokoh saya, ini adalah peristiwa langka yang bisa ia saksikan secara langsung. Saat inilah secara eksplisit terlihat bahwa sebagai pebisnis kuliner, ia masih mengagumi pekerjaan petani yang sebenarnya adalah identitas dari bangsa Indonesia itu sendiri.

Respon akan selalu muncul berdampingan dengan adanya stimulus sehingga rewpon akan muncul ketika adanya stimulus yang diberikan oleh seseorang atau dari lingkungan (Partiningsih, 2018, p. 6). Respon yang ditunjukkan oleh tokoh saya terhadap stimulus yang diberikan berupa respon positif. Hal ini dikarenakan ia nampak begitu semangat hingga ia berniat untuk segera men-charge baterai kameranya untuk mengabadikan momen-momen langka itu. Adapun jenis respon yang ditunjukkan oleh tokoh saya yaitu instrumental response.

Selanjutnya, lingkungan sosial mengenai panen tersebut masih memberi stimulus bagi tokoh saya. Hal ini tidak dapat dipungkiri, karena studio tokoh saya dibangun di samping sawah yang menghijau dan menguning pada masanya, sehingga kegiatan panen bukanlah aktivitas yang asing di lingkungan ini. Adapun uraiannya sebagai berikut

Petang sudah menjelang. Satu persatu si ibu meninggalkan pematang. Hanya si ibu tua yang masih bertahan. Dia masih melakukan gerakan yang sama: membungkuk mengambil jerami mengangkatnya tinggi ke udara.. (Kembangmanggis, 2018:88).

Berdasarkan uraian di atas, digambarkan waktu telah menjelang petang. Para petani mulai meninggalkan hamparan sawah yang menguning. Di sana, dalam tangkapan mata tokoh saya, hanya tersisa seorang ibu tua yang masih melakukan aktivitas seperti sebelumnya. Gerakan yang dilakukannya sama, tak berubah. Hal ini yang membuat tokoh saya semakin merasa simpati kepada petani, terutama si ibu tua itu.

Uraian di atas masih tergolong ke dalam bentuk stimulus tak terkondisi. Hal ini dikarenakan meskipun tokoh saya telah menerima stimulus, namun stimulus tersebut tidak diciptakan oleh si ibu tua itu. Bahkan si ibu tua itu tidak tahu kalau sejak tadi setiap gerakannya di amati oleh tokoh saya. Artinya, tidak ada tujuan apapun dari si ibu tua tersebut terhadap tokoh saya. Ia berdiri di pematang tersebut hanya untuk memanen padi, tidak ada tujuan khusus selain itu. Dalam hal ini, tokoh saya yang berusaha menciptakan stimulus itu datang sendiri akibat ketertarikannya dengan panen, ia rela 
menontoni aktivitas panen hingga petang. Adapun respon dari tokoh saya mengenai stimulus di atas yaitu sebagai berikut.

\section{Tapi setelah menontoni bagaimana beratnya pekerjaan petani, saya jadi bertekad untuk menghargai kembali nasi. Setinggi-tingginya (Kembangmanggis, 2018, p. 90-91).}

Kutipan di atas menggambarkan bahwa tokoh saya begitu peduli dengan peristiwa panen tersebut. Ia baru menyadari bahwa ternyata tugas seorang petani sangatlah berat. Ia kemudian bertekad untuk kembali menghargai nasi. Hal ini merupakan bentuk perubahan tingkah laku tokoh saya atas stimulus yang diberikan. Respon mengenai menghargai nasi sama dengan menghargai pekerjaan petani yang selama ini sering diremehkan oleh kebanyakan orang. Masyarakat saat ini cenderung menganggap bahwa pekerjaan sebagai petani adalah pekerjaan yang rendah. Pekerjaan yang elit saat ini identik dengan pekerjaan kantor. Pernyataan ini tanpa mereka sadari bahwa tanpa adanya petani, maka tidak mungkin ada wujud nasi seperti yang kita makan selama ini. Maka dari itu, semua pekerjaan sejatinya sama, mereka bekerja dibidangnya masingmasing, berkutat pada keahliannya dengan serius tanpa mencibir jenis pekerjaan lain.

\section{c. Menghargai Orang Lain}

Setelah mendapatkan stimulus dari lingkungan pada pembahasan sebelumnya, yaitu di sawah, selanjutnya stimulus diterima tokoh saya dari Bu Klengis, seseorang yang rutin setiap pagi mengambil air jenih di keran studio milik tokoh saya. Adapun kutipannya sebagai berikut.

Bu Klengis selama ini sering datang ke studio untuk menawarkan minyak kelapa. Diisi dan botol aqua $660 \mathrm{ml}$. harganya 20.000. padahal, di pasar hanya 12.000. paling mahal 15.000 (Kembangmanggis, 2018, p. 100).

Kutipan di atas menjelaskan bahwa Bu Klengis selain datang ke studio untuk mengambil air, ia juga menawarkan minyak kelapa buatannya. Tidak hanya minyak kelapa, ia juga menjual klengis. Klengis buatannya diakui oleh tokoh saya sebagai klengis terenak yang pernah ia makan. Harga yang dibandrol lebih mahal dari harga pasar. Inilah stimulus yang diterima oleh tokoh saya. Stimulus datang dari Bu Klengis yang menawarkan kelapanya.

Stimulus dalam uraian di atas tergolong ke dalam jenis stimulus terkondisi, karena adanya tujuan yang diharapkan dapat mengubah atau mempengaruhi tingkah laku individu. Dalam hal ini, tujuan tersebut berupa agar tokoh saya mau membeli minyak kelapa buatan $\mathrm{Bu}$ Klengis. Adapun respon yang ditunjukkan oleh tokoh saya sebagai berikut.

Ketika saya pulang, saya memarahi diri sendiri. Hanya karena dia memasang harga 5.000 kebih tinggi pada minyak kelapanya, saya tidak mau membelinya. Hanya karena dia memasang 4.000 lebih tinggi harga klengis-nya, saya tidak pernah mau memesannya. Padahal setiap rupiah sangat berati baginya. Suaminya, teman Pak Jumu, sudah lama sakit. Bu Klengis harus mencari penghasilan sendiri (Kembangmanggis, 2018, p. 101-102). 
Saya menjadikan Bu Klengis sebagai sahabat saya juga. Mendorong semangatnya, bila dia berkelah-keluh (Kembangmanggis, 2018, p. 104).

Kutipan di atas menceritakan bahwa saat itu tokoh saya sedang mencari sawah baru Pak Purna hingga tanpa sengaja ia melihat rumah Bu Klengis yang ternyata sangat tidak layak. Sesampainya di studio, ia merasa menyesal karena selama ini telah berpikiran buruk kepada $\mathrm{Bu}$ Klengis hanya karena Bu Klengis menjual dagangannya lebih mahal. Meski mahal, terbukti bahwa Klengisnya lah yang paling enak. Ia memarahi dirinya sendiri lantaran selama ini dirasa terlalu perhitungan dengan $\mathrm{Bu}$ Klengis. Setelah mengetahui keadaan sosial ekonomi Bu Klengis, tokoh saya kemudian menjadikan Bu Klengis sebagai sahabatnya. Selain itu, tokoh saya juga menjadi penyemangat $\mathrm{Bu}$ Klengis saat ia sedang berkeluh kesah dengan hidupnya.

Bentuk memarahi diri sendiri inilah yang termasuk dalam bentuk respon oleh tokoh saya. Respon yang ditunjukkan oleh tokoh saya termasuk ke dalam respon positif karena menuju pada perubahan perilaku yang lebih baik. Adapun bentuk perubahan perilaku yang tergambar dalam kutipan tersebut adalah menghargai orang lain. Menghargai dalam artian bahwa tidak mudah berburuk sangka kepada individu yang struktur sosialnya berada di bawah tokoh saya.

\section{SIMPULAN}

Selama tokoh saya tinggal di Ubud, Bali banyak pelajaran kehidupan yang didapatkannya. Pembelajaran tersebut didapat melalui stimulus dan respon yang diterima dan ditunjukkan oleh tokoh saya melalui perspektif behaviorisme Skinner. Adapun kesimpulan yang diperoleh dari penelitian ini adalah tokoh saya mengalami perubahan perilaku berupa lebih menghargai pemberian, lebih menghargai pekerjaan, dan lebih menghargai orang lain. Menghargai pemberian ditunjukkan dengan adanya stimulus yang diberikan oleh Pak Jumu, Bapak Nangka, dan lingkungan Ubud. Menghargai pekerjaan ditunjukkan dengan adanya stimulus yang diberikan oleh lingkungan, dalam hal ini peristiwa panen. Terakhir, menghargai orang lain ditunjukkan dengan adanya stimulus yang diberikan oleh tokoh Bu Klengis.

\section{UCAPAN TERIMA KASIH}

Penulis ucapkan terima kasih kepada Universitas Muhammadiyah Malang khususnya prodi Pendidikan Bahasa Indonesia yang telah membekali mahasiswanya dalam menulis artikel sehingga artikel ini dapat terselesaikan. Ucapan terima kasih juga penulis sampaikan kepada Ibu Dr. Ekarini Saraswati, M. Si selaku dosen pengampu mata kuliah psikologi sastra yang telah memberikan bimbingan selama proses penulisan artikel berlangsung. Ucapan terima kasih juga penulis sampaikan kepada kedua orang tua yang selalu mendukung baik berupa moral serta spiritual sehingga membuat penulis begitu bersemangat dalam menulis artikel ini. 


\section{DAFTAR RUJUKAN}

Alifasari, D. (2017). Kepribadian Tokoh Jiwa dalam Novel Lelaki Terakhir yang Menangis di Bumi Karya M Aan Mansyur(Kajian Psikologi Behaviorisme B.F. Skinner). Bapala, 1-12.

Andalas, E. F. (2017). Eskapisme Realitas dalam Dualisme Dunia Alice Telaah Psikologi Sastra Film Alice in Wonderland (2010). Kembara, Vol 3 (2).

Astari, S. F., Qomariyah, U., \& Andalas, M. I. (2019). Perilaku Tokoh Indigo Dalam Novel Danur Karya Risa Saraswati: Kajian Psikologi Sastra. Jurna Sastra Indonesia , 68-77.

Indayani, A., Sedanayasa, G., \& Antari, N. N. (2014). Penerapan Konseling Behavioral Dengan Teknik Penguatan Positif Sebagai Upaya Untuk Meminimalisasi Perilaku Membolos Pada Siswakelas X.1 Sma Negeri 1 Sawan Tahun Ajaran 2013/2014. Jurnal Ilmiah Undiksa, 1-10.

Kharisma, V. (2018). Hegemoni Negara Terhadap Warga Etnis Tionghoa dalam Novel Dimsum Terakhir Karya Clara Ng. Sapala, vol 5(1): 1-9.

Mauludiyah, N., Mudjianto, \& Kamal, M. (2012). Kepribadian Tokoh Roda Savitri Darsono Dalam Novel Misteri Sutra Yang Robek Karya S. Mara Gd (Kajian Psikologi Behavioral Tokoh Cerita). Jurnal Sastra Indonesia, 1-10.

Partiningsih. (2018). Kepribadian Behaviorisme Tokoh Anyadalam Novel Critical Eleven Karya Ika Natassa:Kajian Psikologi Skinner. Bapala, 1-10

Ramadhan, M. R. (2019). Dinamika Kepribadian Tokoh Utama Novel Alif karya Taufiqurrahman Al Azizy Tinjauan Psikologi Sastra. Padang: Universitas Andalas.

Ratna, N. K. (2013). Teori, Metode, dan Teknik Penelitian Sastra. Yogyakarta: Pustaka Pelajar.

Romadhon. (2015). Perilaku Tokoh Utama Novel Saksi Mata Karya Suparto Brata: Kajian Psikologi Sastra. Semarang: Universitas Negeri Semarang.

Zaini, R. (2014 ). Studi Atas Pemikiran B.F. Skinner Tentang Belajar. Terampil , 118129. 